\title{
Development of bladder stone after tension free vaginal tape procedure: a case report
}

\author{
Gerilimsiz vajinal bant işleminden sonra mesane taşı gelişimi: Bir olgu raporu
}

\author{
Arman Özdemirl ${ }^{1}$ Seda Çakır ${ }^{2}$, Hamdullah Sözen², Ahmed Namazov², Yeşim Akdemir ${ }^{2}$, Ateş Karateke ${ }^{2}$ \\ 'Department of Urology, Zeynep Kamil Training and Research Hospital, Istanbul, Turkey \\ ${ }^{2}$ Department of Urogynecology, Zeynep Kamil Training and Research Hospital, istanbul, Turkey
}

\section{Abstract}

We present a case of a bladder stone which formed on the intravesical portion of tension free vaginal tape material secondary to bladder perforation. 8 years previously, a tension free vaginal tape (TVT) operation was performed. The patient was referred to hospital with persistent urinary infection and urinary incontinence. An intravesical stone that had formed on the TVT sling material was detected by cystoscopy and it was removed with the sling material by a supra pubic cystostomy approach. When evaulating patients presenting with urinary symptoms after a TVT procedure, bladder complications should be kept in mind. (J Turkish-German Gynecol Assoc 2011; 12: 256-8)

Key words: Bladder stone, tension -free vaginal tape, perforation, urinary incontinence

Received: 18 August, 2010

Accepted: 20 September, 2010
Özet

Mesane perforasyonuna ikincil gerilimsiz vajinal bant materyalinin intravezikal kısmı üzerinde oluşan bir mesane taşı olgusunu sunuyoruz. Gerilimsiz vajinal bant (GVB) operasyonu 8 yl önce yapılmıştı. Hasta sebat eden üriner enfeksiyonu ve idrar tutamama sikayeti ile hastaneye sevk edilmişti. GVB askı materyali üzerinde oluşan mesane içi taş, sistoskopi ile saptandı ve suprapubik sistostomi yaklaşımılla askı materyaliyle çıkarıldı. Bir GVB işleminden sonra üriner semptomlarla gelen hastalar değerlendirilirken mesane komplikasyonlan akılda tutulmalıdır.

(J Turkish-German Gynecol Assoc 2011; 12: 256-8)

Anahtar kelimeler: Mesane taşı, gerilimsiz vajinal bant, perforasyon, idrar tutamama

Geliş Tarihi: 18 Ağustos 2010

Kabul Tarihi: 20 Eylül 2010

\section{Introduction}

Urinary stress incontinence is a voiding dysfunction characterized by involuntary leakage of urine on effort, exertion, sneezing or caughing (1).

In 1995 Ulmsten et al proposed a surgical procedure during which synthetic polypropylene mesh is inserted under the mid urethra to restore continence (2). Studies on tension free vaginal tape surgery have demonstrated a 5 year success rate ranging from $80 \%$ to $90 \%$ in the general population $(3,4)$.

Owing to the anatomic relationships several urological complications can be seen in patients who have undergone the tension free vaginal tape (TVT) procedure. Bladder perforation is the most frequent intraoperative complication of TVT. Tamussino et al. reported perforation rates of $4.4 \%$ in TVT cases with previous surgery and $2 \%$ in the absence of any previous surgery (5).

In this article we present the case of a 56 year-old female who underwent the TVT procedure eight years previously. During the eight years a vesical calculus was formed on the polipropylene mesh.

\section{Case Report}

A fifty six year-old woman was referred to our hospital with persistant urinary infection, stone and urinary incontinence.
Her history revealed that a TVT surgical procedure was performed eight years previously. Two years after the operation she attended various hospitals due to dysuria and voiding pain. Various antibiotherapies were prescribed to treat the urinary system infection. It was learnt from the patient's history that the patient had been treated five to six times a year by antibiotherapies owing to urinary system infection.

Two weeks earlier her urine examination demonstrated pyuria, microscopic hematuria and oxalate crystals and she was referred to our clinic with urinary stone. Urinary ultrasound was performed and a vesical stone of $5 \times 2 \mathrm{~cm}$ in dimension was seen in the right corner of bladder.

Cystoscopy performed on the patient showed a $5 \mathrm{~cm}$ portion of the tape passing across on the right side of bladder. On the polypropylene mesh there was a $2 \times 5 \mathrm{~cm}$ bladder stone. In addition on pelvic examination kelloid formation was found within the right inguinal region. She had right inguinal pain with deep abdominal palpation.

With these findings, the surgical procedure of cystostomy was decided on. The synthetic material and vesical stone were removed and BURCH colposuspension procedure was performed for the symptoms of urinary incontinence. A Foley`s catheter was left for five days to allow healing of bladder mucosa (Figure 1, 2)

Address for Correspondence: Ahmed Namazov, Zeynep Kamil Mahallesi, Üsküdar, İstanbul, Turkey

Phone: +902164958382 e.mail: enamazov@gmail.com

(C) Copyright 2011 by the Turkish-German Gynecological Education and Research Foundation - Available online at www.jtgga.org doi:10.5152/jtgga.2011.59 


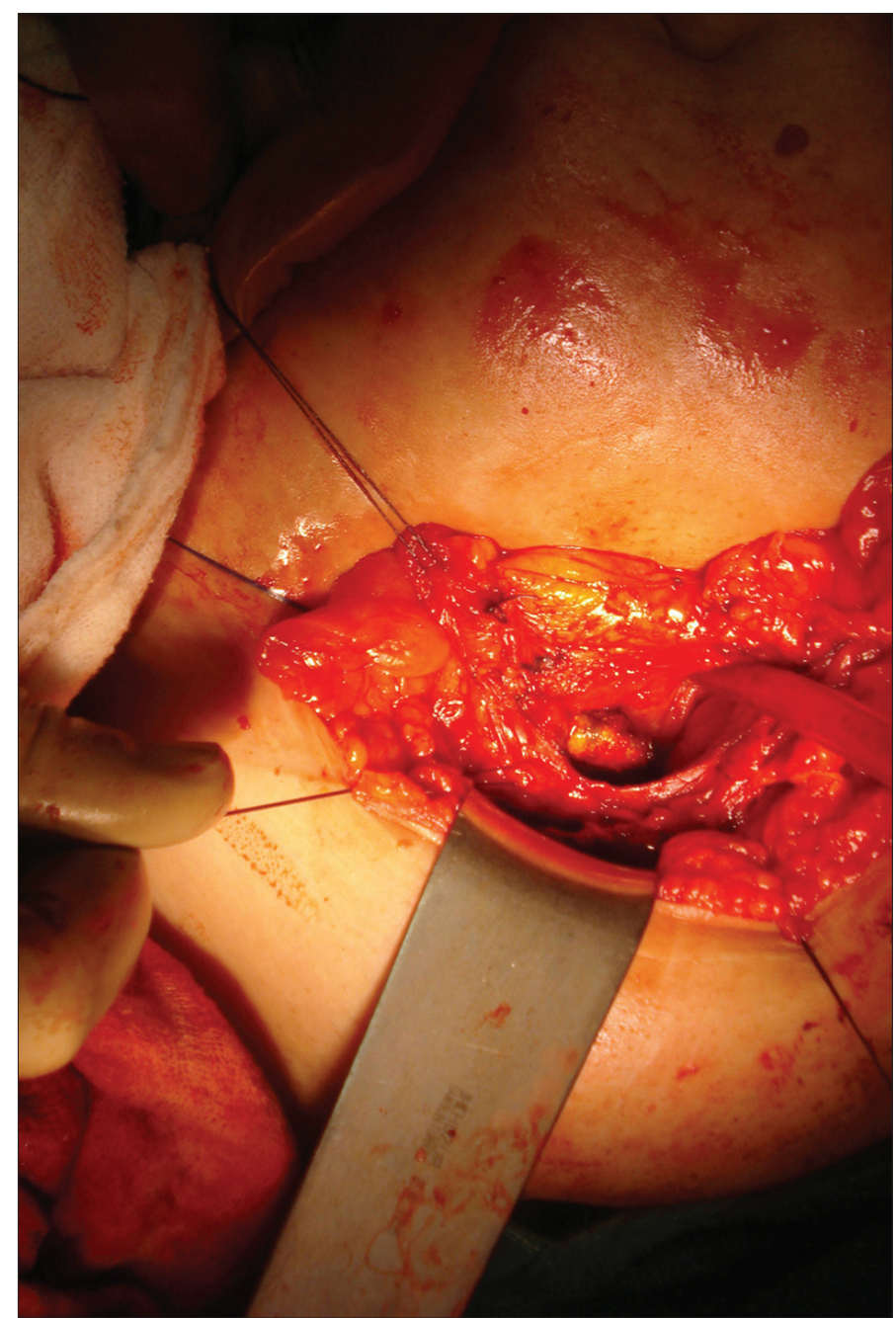

Figure 1. Cystostomy was performed

\section{Discussion}

Various urogynecological clinics worldwide have been performing tension free vaginal tape (TVT) operation since its original introduction by Ulmsten in 1996 (2). Even though its safety and low number of complications were emphasised by the first description, a series of complications develop from this procedure. Bladder perforation, postoperative urinary retention, bruises, urinary urgency, dyspareunia and long term catheterization were reported by different clinics. Bladder perforation and stone formation on the TVT material have been described rarely (3-9).

After the TVT operation, bladder perforation and vesical stone formation were investigated in the literature and it was learnt from the literature that patients generally presented with painful urination, urinary sediments and pyuria. and different surgical approaches were performed. Irer et al. performed bladder endoscopic lithotripsy and simultaneously removed the synthetic material (7). Tzortis et al. performed suprapubic cystostomy and removed the lithiasis and synthetic material (8). Mustafa et al performed endoscopic pneumatic lithotripsy and transurethral mesh resection (9).

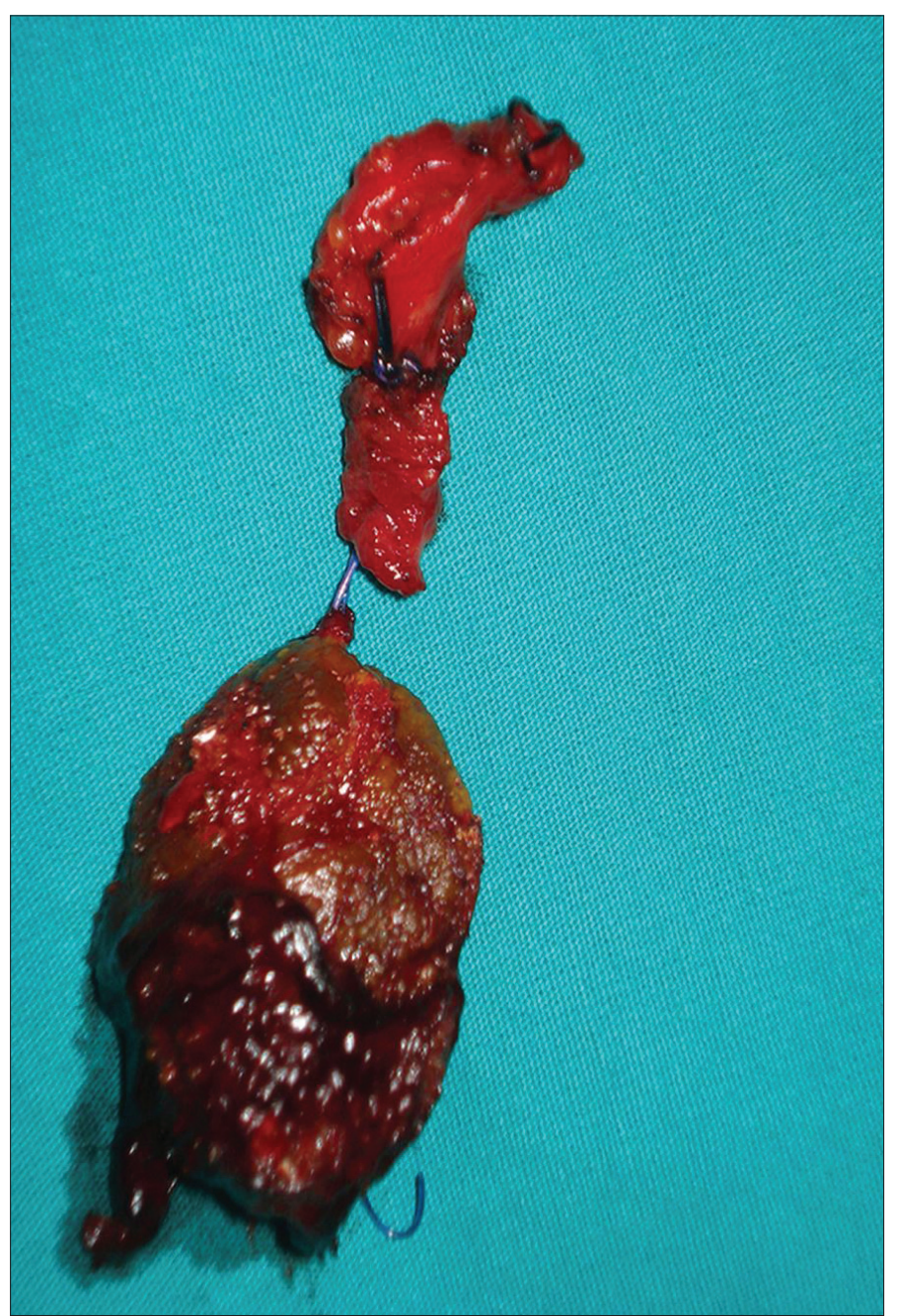

Figure 2. Polypropylene mesh and bladder stone were removed

In our case it was decided to remove the mesh and stone in the bladder by cystostomy because of the ineffectiveness of lithotripsy in breaking the $2 \times 5 \mathrm{~cm}$ stone, existence of kelloid structure in the right inguinal ragion caused by polypropylene mesh and continuation of urinary incontinence complaints. After this procedure, a Burch colposuspension operation was applied due to urinary stress incontinence.

Within the 6 months postoperative period, the urinary system infections which had previously recurred 5 to 6 times each year after the TVT operation disappeared.

Although the TVT operation still preserves its popularity due to its high success rates, various complications may appear due to failure of management. In our study stemming from the bladder perforation during the management of a TVT operation, a bladder stone formed in the bladder.

In recurring urinary system infections after the TVT operation and observation of crystalloids on urinary examination, bladder perforation should be kept in mind and cystoscopy should be performed. In order to remove the stone the procedure should be adapted taking into account the specifics of each patient and cystostomy and endoscopic lithotropsy must be considered as important. 


\section{Conflict of interest}

No conflict of interest was declared by the authors.

\section{References}

1. Abrams P, Cardozo L, Fall M, Griffiths D, Rosier P, Ulmsten U, et al. The standardisation of terminology of lower urinary tract function: report from the standardisation sub-committee of the International Continence Society. Neurourol Urodyn 2002; 21: 167-78. [CrossRef]

2. Ulmsten U, Henriksson L, Johnson P, Varhos G. An ambulatory surgical procedure under local anesthesia for treatment of female urinary incontinence. Int Urogynecol J Pelvic Floor Dysfunct 1996; 7: 81-5. [CrossRef]

3. Boustead GB. The tension-free vaginal tape for treating female stress urinary incontinence. BJU Int 2002; 89: 687-93. [CrossRef]

4. Nilsson CG, Kuuva N, Falconer C, Rezapour M, Ulmsten U. Longterm results of the tension-free vaginal tape (TVT) procedure for surgical treatment of female stress urinary incontinence. Int Urogynecol J Pelvic Floor Dysfunct 2001; 12: 5-8. [CrossRef]

5. Tamussino K, Hanzal E, Kölle D, Ralph G, Riss P. The Austrian tension-free vaginal tape registry. Int Urogynecol J Pelvic Floor Dysfunct 2001; 12: 28-9. [CrossRef]

6. Peyromaure M, Dayma T, Zerbib M. Development of bladder stone following a tension-free vaginal tape intervention. J Urol 2004; 171: 337. [CrossRef]

7. Irer B, Aslan G, Cimen S, Bozkurt O, Celebi I. Development of vesical calculi following tension-free vaginal tape procedure. Int Urogynecol J Pelvic Floor Dysfunct 2005; 16: 245-6. [CrossRef]

8. Tzortzis V, Mitsogiannis IC, Moutzouris G, Aravantinos E, Anagnostou $\mathrm{T}$, Gravas $\mathrm{S}$, et al. Bladder stone formation after a tension-free vaginal tape procedure: report on two cases. Urol Int 2007; 79: 181-2. [CrossRef]

9. Mustafa M, Wadie BS. Bladder erosion of tension-free vaginal tape presented as vesical stone; management and review of literature. Int Urol Nephrol 2007; 39: 453-5. [CrossRef] 